\title{
Redox Reactions Values of AlZn + Ag Eutectoid Chemical Composition*
}

\author{
Socorro Valdez ${ }^{\#}$, Jorge A. Ascencio ${ }^{1}$, Angélica Meneses², Sid R. Casolco ${ }^{3}$ \\ ${ }^{1}$ Instituto de Ciencias Físicas, Universidad Nacional Autónoma de México, Cuernavaca, México \\ ${ }^{2}$ Facultad de Farmacia, Universidad Autónoma del Estado de Morelos, Cuernavaca, México \\ ${ }^{3}$ Instituto Tecnológico y de Estudios Superiores de Monterrey, Vía Atlixcáyotl, México \\ Email: ${ }^{\text {svaldez@fis.unam.mx }}$
}

Received 18 May 2014; revised 3 July 2014; accepted 31 July 2014

Copyright (C) 2014 by authors and Scientific Research Publishing Inc.

This work is licensed under the Creative Commons Attribution International License (CC BY).

http://creativecommons.org/licenses/by/4.0/

(c) (i) Open Access

\section{Abstract}

The effect of IB element additions [Ag] on the corrosion behavior of AlZn alloy has been investigated. The potentiodynamic polarization curves revealed that the corrosion behavior of $\mathbf{S S}_{\mathrm{Al}}, \mathbf{S S}_{\mathrm{Zn}}$ and $\mathrm{AgZn}_{3}$ phases was significantly influenced by IB element content. The electrochemical investigations showed that the corrosion rate increased with the IB-element additions. Furthermore, it was also evidenced the formation of a passive layer for the highest Ag content alloys; the passivity of this layer could be broken due to the presence of the intermetallic compound (IMCs) AgZn

\section{Keywords}

\section{AlZn Alloys, Ag Additions, Polarization Curve, $\operatorname{AgZn}_{3}$ Precipitate}

\section{Introduction}

AlZn alloys exhibit attractive physical, mechanical and superplastic properties in conjunction with good abrasion and wear resistances, making them the choice for many end-use applications [1].

The addition of small amounts of silver to some aluminum alloys acts to exert a marked effect on their structure and microstructural characteristics. However, limited studies address the corrosion behavior of these alloys. The addition of small amounts of copper to AlZn alloy increases the tensile strength, creep strength and corrosion resistance; on the contrary, copper causes dimensional instability [2].

Other elements, such as $\mathrm{Cr}, \mathrm{Mn}$ and $\mathrm{Zr}$ are generally added to control grain structure and weldability, mainly. However, few studies have been reported about the corrosion behavior taking into account the effect of several

\footnotetext{
${ }^{*}$ The nominal chemical composition was obtained by Inductive coupled plasma (ICP).

\#Corresponding author.
} 
microconstituentes. The mechanical, corrosion and metallurgical properties of these alloys vary according to their chemical composition and microstructure.

Microstructural modification in conjunction with processing methods could enhance the corrosion susceptibility as well as the corrosion resistance [3]. Therefore, the main goal of this work is to investigate the influence of IB element (Ag) contents on the redox reaction behavior of Al-Zn alloy, especially in the corrosion performance. The electrochemical parameters of the AlZnAg alloys were deduced by potentiodynamic polarization curves.

\section{Methodology Experimental}

Alloys were prepared by melting $\mathrm{Al}$ and $\mathrm{Zn}$ (ingots 99.8\%) pieces in a steel crucible, in a resistance electrical furnace at constant temperature of $700^{\circ} \mathrm{C}$.

A flux mixture of salts was used to avoid contact with the environment preventing elements oxidation. In addition, in order to compensate some oxidation losses, $3 \mathrm{wt} \% \mathrm{Al}$ and $10 \mathrm{wt} \% \mathrm{Zn}$ were added in excess to the molten bath. Four different Ag contents (0.5, 2.5, 3.5, and 4.5 wt\%) were added to the AlZn melt alloy. Molten Ag was directly added to the AlZn melt alloy via refractory feeder tip into the steel crucible at $1150 \mathrm{rpm}$ during 15 minutes in order to achieve better homogenization. The AlZnAg melt was poured into a steel mold to form ingots of $100 \mathrm{~mm} \times 150 \mathrm{~mm} \times 20 \mathrm{~mm}$.

Their nominal chemical composition was obtained by ICP presented in Table 1 . The samples surfaces have been prepared by the standard technique of grinding with SiC up to 1000-grade emery paper and mechanical polishing with $\mathrm{Al}_{2} \mathrm{O}_{3}$ suspension solution. The working electrode surfaces from every AlZn alloy were degreased in acetone; washed thoroughly in double distilled water and kept in a desiccator prior to immersion and potentiodynamic polarization tests. A saline solution, $3.5 \% \mathrm{NaCl}$, prepared from analytical grade reagents with deionized water was utilized during 1, 3, 7, 14 and 28 days for weight lost tests.

AlZnAg specimens were cut in squares samples. Afterwards, specimens were cleaned by immersion in a solution of $50 \mathrm{vol} \%$ nitric acid $\left(\mathrm{HNO}_{3}\right)$ for 3 min in accordance with ASTM Standard G31 [4]. Finally, samples were dried in a hot stream air before weighting.

The weight loss estimation were conducted according to the ASTM G1-90 [5] recommended practice. Potentiodynamic polarization curves were carried out in electrochemical cell using the three-electrode set-up. A saturated calomel reference electrode (SCE) was used to measure the corrosion potential. A platinum wire auxiliary electrode was used as counter electrode. Working electrodes were embedded in epoxy resin with an exposed surface area of $1 \mathrm{~cm}^{2}$.

Polarization test was carried out in a corrosion cell containing an aerated substitute ocean water electrolyte, prepared with analytical grade reagent $\mathrm{NaCl}$ and deionized water, with an initial $\mathrm{pH}$ of 8.3 according to ASTM D1141 [6].

The potentiodynamic current-potential curves were recorded by changing the working electrode potential from $-700 \mathrm{mv}$ to $+700 \mathrm{mV}$ at open-circuit potential (OCP), $E_{\text {corr }}$, with $1 \mathrm{mV} \cdot \mathrm{s}^{-1}$ scan rate at $22^{\circ} \mathrm{C}$. In order to determinate the current density $i_{\text {corr }}$, the polarization resistance measured from the test was used in the StearnGeary equations [7] as shown in Equation (2):

$$
\begin{gathered}
B=\frac{\beta_{a} \beta_{c}}{2.303\left(\beta_{a}+\beta_{c}\right)} . \\
R_{p}=\frac{B}{i_{c o r r}}=\frac{(\Delta E)}{(\Delta i)_{\Delta E \rightarrow 0}} .
\end{gathered}
$$

The $B$ constant is determined using both cathodic and anodic branches by anodic and cathodic Tafel slopes $\beta_{\text {a }}$ and $\beta_{\mathrm{c}}$ by Equation (1). $R_{p}$ corresponds to the polarization resistance, that is, the ratio between the potential shift $\Delta E$ and the corresponding current change $\Delta i$ in an experimental polarization test within a few millivolts of the corrosion potential.

\section{Results and Discussion}

Figure 1 shows the polarization curves for AlZnAg alloys in 3.5\% NaCl solution. Polarization curves are the relationship between the applied potential $\left(E_{\text {app }}\right)$ with current density $(i)$ generated with the working electrode 
Table 1. Chemical composition of AlZn + Ag alloys (wt\%) balanced with aluminium.

\begin{tabular}{cccc}
\hline \multirow{2}{*}{ Alloy type } & \multicolumn{3}{c}{ Chemical alloying elements } \\
\cline { 2 - 4 } & $\mathrm{Zn}$ & $\mathrm{Ag}$ & Others \\
\hline A & 78.15 & 0.50 & 0.016 \\
B & 78.00 & 2.50 & 0.020 \\
C & 78.21 & 3.50 & 0.018 \\
D & 78.05 & 4.50 & 0.021 \\
\hline
\end{tabular}

a. The AlZn chemical compositions are close to the eutectic reaction.

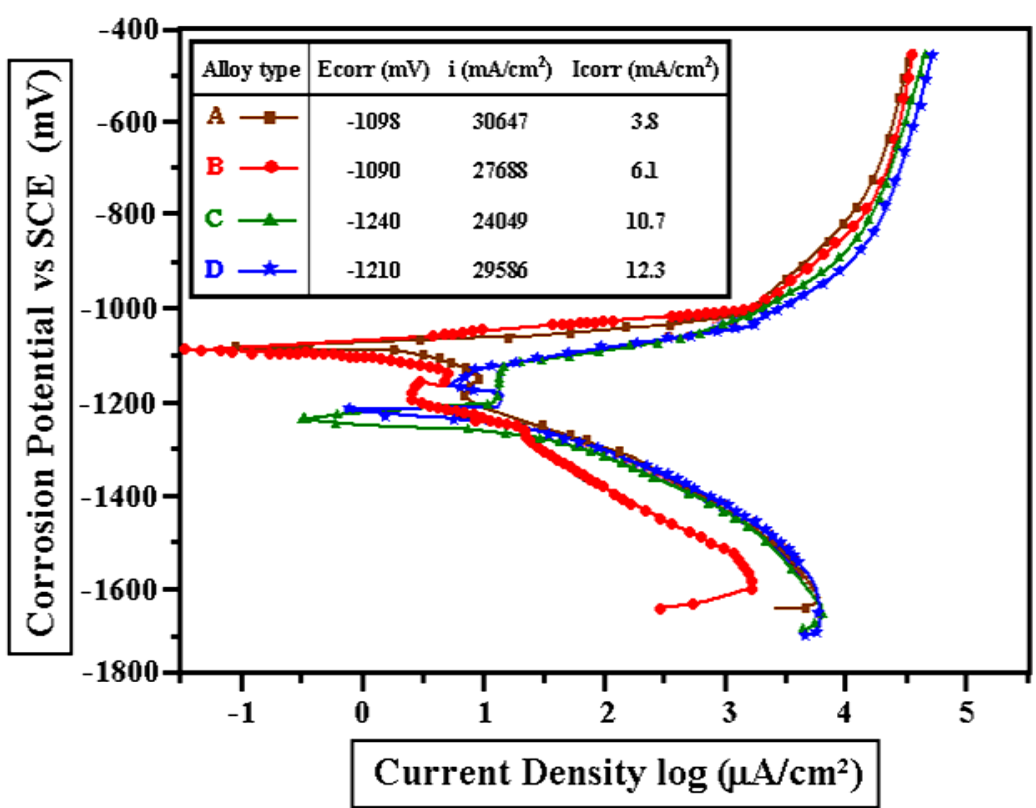

Figure 1. Potentiodynamic polarization curves for AlZnAg alloys in $3.5 \% \mathrm{NaCl}$.

AlZnAg, and the counter electrode.

The AlZnAg with 3.5 and 4.5 wt\% Ag showed the lowest $E_{\text {corr }}$ values close to $-1200 \mathrm{mV}$; an active-passive behavior was identified along the anodic branch. On the other hand, alloys with 2.5 and 0.5 wt $\%$ Ag content did not exhibit passive regions, only active dissolution with an $E_{\text {corr }}$ value close to $-1100 \mathrm{mV}$ was detected. The corrosion current density value, $i_{\text {corr, }}$ increased at higher Ag content. The lowest $i_{\text {corr }}$ value, $3.8 \mu \mathrm{A} / \mathrm{cm}^{2}$, corresponds to $0.5 \% \mathrm{Ag}$. On the contrary, the highest value, $12.3 \mu \mathrm{A} / \mathrm{cm}^{2}$, is ascribed to $4.5 \% \mathrm{Ag}$.

The passive current density values became smaller as function of the Ag percentage. Thus, it is clear the beneficial effects of increasing the Ag contents in AlZn alloys in the passive region formation. As expected, at open circuit potentials (OCP) the corrosion rates increased.

The OCP's values shifted to anodic direction. However, as the polarization increases and the passive region were trespassed, it is shown that the anodic current density values were very similar for all alloys regardless the Ag content. This behavior suggests that corrosion process is diffusion-controlled through the formed corrosion products. Therefore, these results evidence that the Ag addition does not have a suppressing effect on the anodic reaction as $\mathrm{Cr}, \mathrm{Cu}, \mathrm{Ni}$ and $\mathrm{Ca}$ in steel does [8]. In a similar way, it was reported [9] that the increase on silicon content on AlSi alloys provides a deteriorate effect on the corrosion resistance.

Concerning the cathodic branch, the potentiodynamic curve reveals that the cathodic density currents were similar for all AlZn alloys (0.5, 3.5 and 4.5 wt\% Ag); however, the AlZn-2.5\%Ag alloy showed the lowest value. It is generally accepted that cathodic polarizations represents the oxygen reduction and hydrogen evolution reactions [8] in aerated saline media.

Figure 2 shows the AlZnAg corrosion rates determined by weight loss estimation in function of time in 3.5 wt\% $\mathrm{NaCl}$ solution. 


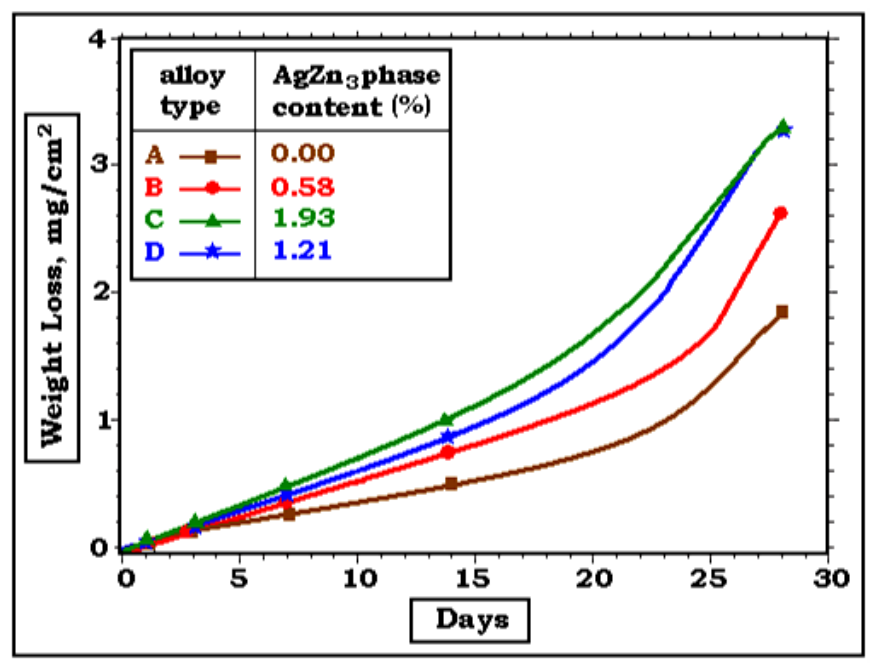

Figure 2. Weight loss estimation of AlZnAg alloys as funtion of time in $3.5 \% \mathrm{NaCl}$ solution.

The four AlZnAg alloys had a slow corrosion rate during the first 72 hours; afterwards, different dissolution processes were achieved. AlZnAg samples revealed that the corrosion rate increases as the Ag content and duration times also increased. This is in agreement with the well-known statement that "internal structure of an alloy controls and modifies the nature and interaction type of the existing defects" [3].

The $\mathrm{AgZn}_{3}$ particles seem to be responsible for the corrosion action due to the fact that they act as local anodes susceptible to localized corrosion. The $\mathrm{AgZn}_{3}$ precipitates represent sites for disruption of any air-formed oxide that protects the alloy; as a consequence the protective film can be broken, exposing the underlying AlZ$\mathrm{nAg}$ alloy to further corrosion. As expected, alloys with 3.5\% and 4.5\% Ag content had the highest $\mathrm{AgZn}_{3} \mathrm{phase}$ content which reported the highest corrosion rates. In addition another consideration should be noted for the alloy with $4.5 \mathrm{wt} \% \mathrm{Ag}$ which exhibited an unexpected corrosion rate.

In accordance to the trend shown in Figure 2, this alloy should have exhibited both the highest weight loss and the highest corrosion rate; however, results along the test did not show this behavior; on the contrary, this alloy enhanced its corrosion resistance compared to $3.5 \mathrm{wt} \% \mathrm{Ag}$. This behavior is probably associated to the fact that $4.5 \mathrm{wt} \% \mathrm{Ag}$ decreased the solubility of $\mathrm{Zn}$ within the $\mathrm{Al}$ matrix. Then, this led an increment in size of $\mathrm{AgZn}_{3}$ particles reducing the number of IMCs. This explanation makes consistency with Saad et al., who reported the enhancement in corrosion resistance when Ag is added to the Zn-Sn eutectic alloy [10]. Because Znrich phase decreases an increment of the solubility in solid solution of $\mathrm{Zn}$ in the Al matrix by Ag addition was observed.

\section{Conclusions}

The Ag addition improves the formation of a passive region. The positive effect is more evident at higher Ag contents (3.5 wt\%). The $\mathrm{AgZn}_{3}$ precipitate activates the corrosion process of the alloy. The amount of precipitate also varies with the Ag addition.

The Ag addition up to $3.5 \mathrm{wt} \%$ clearly increased the corrosion rate but it induced a passive region.

\section{Acknowledgements}

The present project is supported by DGAPA-UNAM program Award No. PAPIIT-IT101112 and for funding the research project CONACyT \#178563.

\section{References}

[1] Yan, L.Z., Zhang, Y.A., Li, X.W., Li, Z.H., Wang, F., Liu, H.W. and Xiong, B.Q. (2014) Effect of Zn Addition on Microstructure and Mechanical Properties of an Al-Mg-Si Alloy. Progress in Nature Science: Materials International, 24, 97-100. http://dx.doi.org/10.1016/j.pnsc.2014.03.003 
[2] Zhang, X., Vu, T.-N., Volovitch, P., Leygraf, C., Ogle, K. and Wallinder, O. (2012) The Initial Release of Zinc and Aluminum from Non-Treated Galvalume and the Formation of Corrosion Products in Chloride Containing Media. Applied Surface Science, 258, 4351-4359. http://dx.doi.org/10.1016/j.apsusc.2011.12.112

[3] Liu, J.-T., Zhang, Y.-A., Li, X.-W., Li, Z.-H., Xiong, B.-Q. and Zhang, J.-S. (2014) Thermodynamic Calculation of High Zinc-Containing Al-Zn-Mg-Cu Alloy. Transactions Nonferrous Metals Society of China, 24, 1481. http://dx.doi.org/10.1016/S1003-6326(14)63216-7.

[4] American Society for Testing and Materials, ASTM G31-72 (1999) Standard Practice for Lab Immersion Corrosion Testing of Metals.

[5] American Society for Testing and Materials, ASTM G1-90 (1999) Standard Practice for Preparing, Cleaning, and Evaluating Corrosion Test Specimens.

[6] Standard Specification for Substitute Ocean Water, ASTM D1141-75.

[7] Chang, Z.-T., Cherry, B. and Marosszeky, M. (2008) Polarisation Behavior of Steel Bar Samples in Concrete in Seawater. Part 2: A Polarization Model Form Corrosion Evaluation of Steel in Concrete. Corrosion Science, 50, 30783086. http://dx.doi.org/10.1016/j.corsci.2008.08.021

[8] Badawy, W.A., El-Sherif, R.M. and Shehata, H. (2009) Electrochemical Stability of Cu-10al-5Ni Alloy in ChlorideSulfate Electrolytes. Electrochemical Acta, 54, 4501-4505. http://dx.doi.org/10.1016/j.electacta.2009.03.040

[9] Osório W.R., Goulart P.R. and Garcia, A. (2008) Effect of Silicone Contente on Microstructure and Electrochemical Behavior of Hypoeutectic Al-Si Alloys. Materials Letters, 62, 365-369. http://dx.doi.org/10.1016/j.matlet.2007.05.051

[10] Saad, G., Fawzy, A. and Shawky, E.J. (2009) Effect of Ag Addition on the Creep Characteristics of Sn-8.8 wt\% Zn Solder Alloy. Alloys and Compounds, 479, 844-850. http://dx.doi.org/10.1016/j.jallcom.2009.01.069 
Scientific Research Publishing (SCIRP) is one of the largest Open Access journal publishers. It is currently publishing more than 200 open access, online, peer-reviewed journals covering a wide range of academic disciplines. SCIRP serves the worldwide academic communities and contributes to the progress and application of science with its publication.

Other selected journals from SCIRP are listed as below. Submit your manuscript to us via either submit@scirp.org or Online Submission Portal.
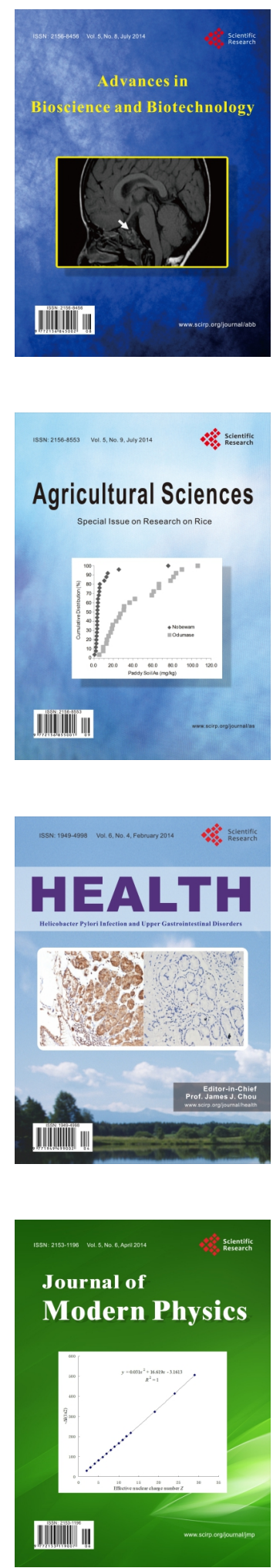
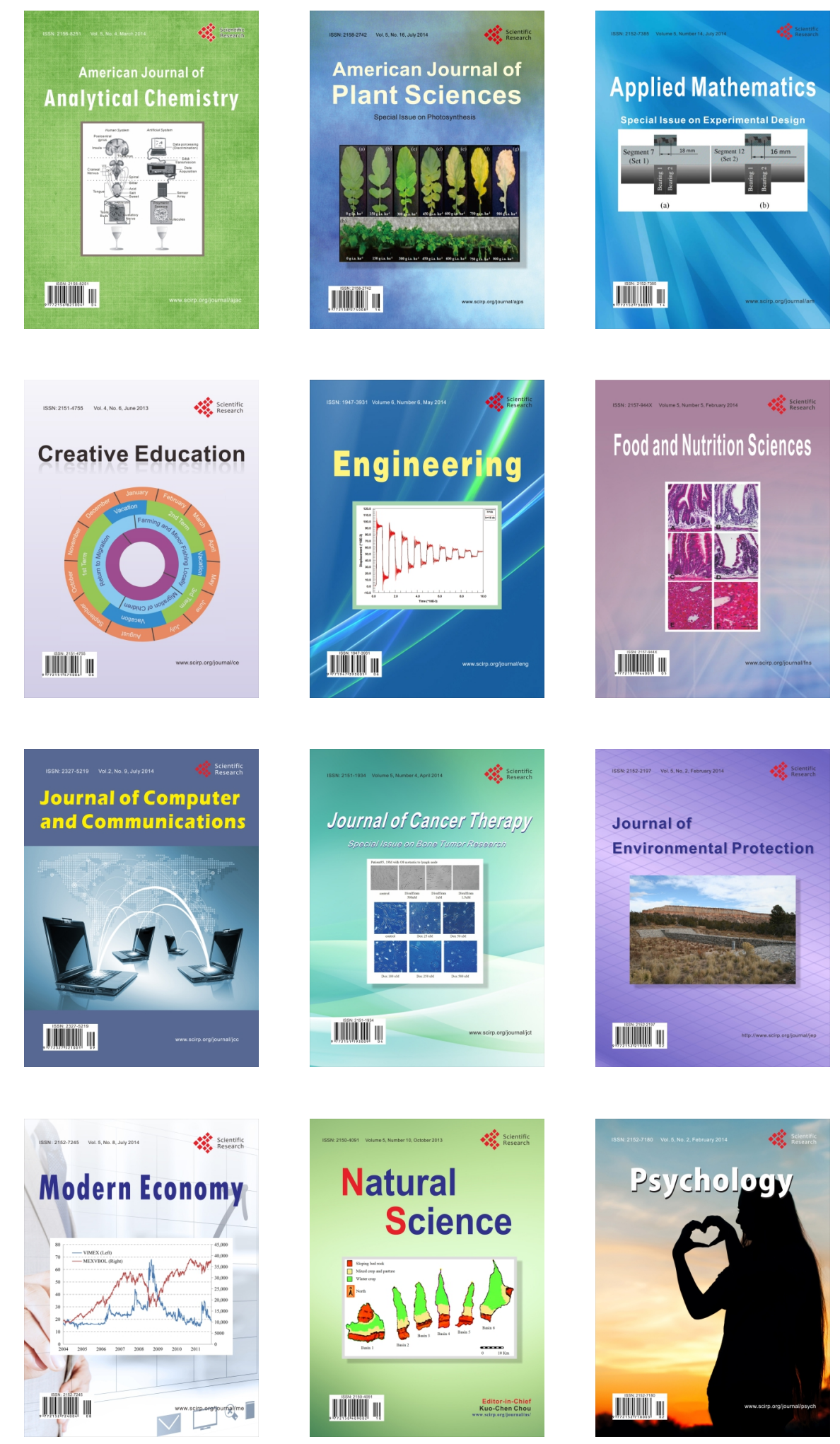